\title{
Rearing Performance of Atlantic Salmon Grown in Circular Tanks with Vertically-Suspended Environmental Enrichment
}

\author{
Misty D. Jones, Eric Krebs, Nathan Huysman, Jill M. Voorhees, Michael E. Barnes \\ South Dakota Game, Fish and Parks, McNenny State Fish Hatchery, Spearfish, SD, USA \\ Email: mike.barnes@state.sd.us
}

How to cite this paper: Jones, M.D., Krebs, E., Huysman, N., Voorhees, J.M. and Barnes, M.E. (2019) Rearing Performance of Atlantic Salmon Grown in Circular Tanks with Vertically-Suspended Environmental Enrichment. Open Journal of Animal Sciences, 9, 249-257.

https://doi.org/10.4236/ojas.2019.92021

Received: March 20, 2019

Accepted: April 16, 2019

Published: April 19, 2019

Copyright $\odot 2019$ by author(s) and Scientific Research Publishing Inc. This work is licensed under the Creative Commons Attribution International License (CC BY 4.0).

http://creativecommons.org/licenses/by/4.0/

c) (i) Open Access

\begin{abstract}
Environmental enrichment is the incorporation of materials into hatchery tanks to simulate a more natural rearing environment. This study investigated the use of a vertically-suspended plastic conduit array as enrichment in $3.63 \mathrm{~m}$ circular tanks during Atlantic salmon (Salmo salar) rearing. After 168 days, feed conversion ratio was significantly improved for salmon reared in tanks with enrichment compared to the barren control tanks. Final tank weights and weight gain were not significantly different, although the difference in mean gain of $182.0 \mathrm{~kg}$ in the enriched tanks compared to $162.9 \mathrm{~kg}$ in the control tanks approached significance. There were no significant differences in individual fish length, weight, or condition factor between the treatments, likely because of large variances in body size due to sexual dimorphism and small sample sizes. The suspended array did not interfere with the hydraulic self-cleaning of the circular tanks. The results of this study support the use of vertically-suspended structures to improve the hatchery rearing performance of Atlantic salmon in circular tanks.
\end{abstract}

\section{Keywords}

Salmonids, Growth, Salmo salar, Vertically-Suspended Array

\section{Introduction}

Environmental enrichment is the addition of material within a barren hatchery rearing unit to imitate natural environments normally encountered by fish. It has been used in an attempt to alter fish behavior and physiology to improve hatchery rearing performance or post-stocking survival [1]-[9]. Forms of environmental enrichment have included natural and artificial plants, sand and gra- 
vel substrate, wood, rocks, and concrete blocks [2] [4] [9]-[14]. While these supplements attempt to replicate a natural environment, they also disrupt the hydraulic self-cleaning of circular tanks. As a result, there may be a potential increase of disease outbreaks and increased labor requirements from hatchery staff [14] [15] [16] [17].

The use of vertically-suspended arrays as environmental enrichment is a recent development. In general, the suspension of vertical structures has improved feed conversion ratios and salmonid growth without disrupting circular tank self-cleaning [14] [18] [19] [20] [21] [22]. In contrast, White et al. [23] did not observe improved hatchery rearing performance with the use of vertically-suspended arrays in juvenile Atlantic salmon (Salmo salar) during a 125 day study. However, the 125-day study duration may not have been long enough to detect any effects from environmental enrichment with Atlantic salmon. Brockmark et al. [12] did not observe any environmental enrichment effects on Atlantic salmon growth until after 311 days of hatchery rearing. Thus, the objective of this study was to evaluate the hatchery rearing performance of Atlantic salmon after long-term rearing with vertically-suspended environmental enrichment.

\section{Methods}

Juvenile Atlantic salmon, Saint John's River strain, were reared initially in $1.8 \mathrm{~m}$ diameter unenriched circular tanks at McNenny State Fish Hatchery in rural Spearfish, South Dakota, USA, using well water at a constant temperature of $11^{\circ} \mathrm{C}$ (water hardness as $\mathrm{CaCO}_{3}=360 \mathrm{mg} / \mathrm{L}$, alkalinity as $\mathrm{CaCO}_{3}=210 \mathrm{mg} / \mathrm{L}$, $\mathrm{pH}$ $=7.6$, total dissolved solids $=390 \mathrm{mg} / \mathrm{L}$ ). On May 23, 2018, approximately 2000 fish (mean $\pm \mathrm{SE}$; total length $=125.4 \pm 3 \mathrm{~mm}$, mean weight $=19.8 \pm 1.5 \mathrm{~g}, \mathrm{~N}=$ 20) were moved into six larger tanks (diameter $=3.63 \mathrm{~m}$, height $=1.09 \mathrm{~m}$, water depth $=0.71 \mathrm{~m}$ ). Each tank initially received $4.60 \mathrm{~kg}$ (approximately 330 fish). The experiment duration was 168 days.

Two different treatments were assigned to the six circular tanks $(\mathrm{N}=3)$. Three control tanks were devoid of any internal structure, while three tanks contained vertically-suspended structure as environmental enrichment, as described by White et al. [23]. All tanks were near fully covered by corrugated plastic overhead covers [24]. The vertically suspended enrichments consisted of 20 hollow plastic polyvinyl chloride $(\mathrm{PVC})$ electrical conduit pipes (diameter $=4.34 \mathrm{~cm}$, length $=0.94 \mathrm{~m}$ ), suspended from attachment points on the overhead covers. The pipes were evenly spaced approximately $16.5 \mathrm{~cm}$ from each other, arranged in an array with an area of $43 \mathrm{~cm} \times 117 \mathrm{~cm}$. The array was situated approximately $58 \mathrm{~cm}$ from the edge of the tank at a quarter turn of the tank away from the spray bar from which water entered the tank (Figure 1(a) and Figure 1(b)).

All fish were fed $3.0 \mathrm{~mm}$ BioVita feed (Bio-Oregon, Longview, Washington, USA) daily over a 12 hour period during daylight hours using automatic belt feeders (Pentair Aquatic Ecosystems, Apopka, Florida, USA). Feeding rates were determined for each experiment by the hatchery constant method [25] with 


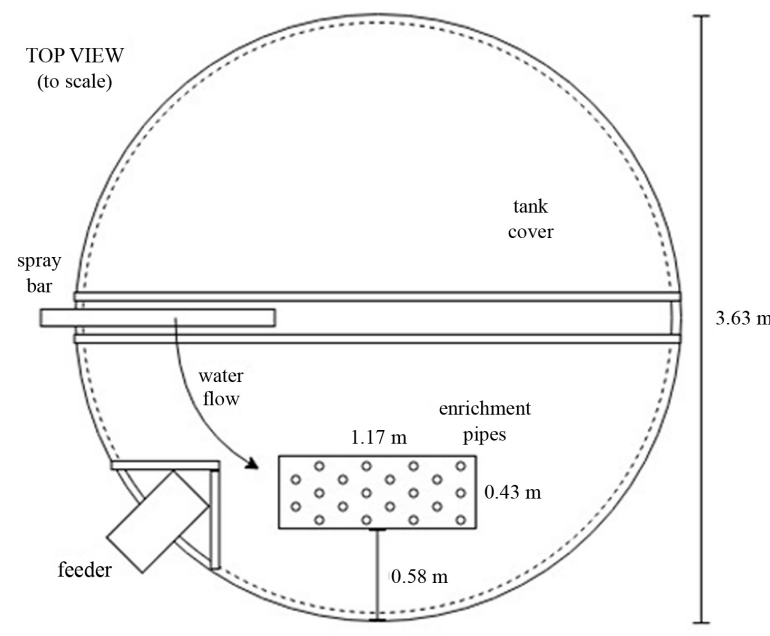

(a)

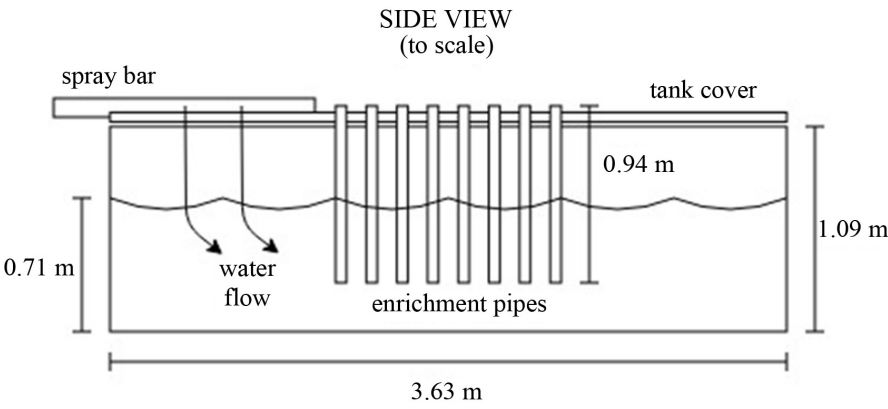

(b)

Figure 1. (a) Top view of a $3.63 \mathrm{~m}$ diameter circular tank indicating location of suspended plastic array used as environmental enrichment; (b) Side view of a $3.63 \mathrm{~m}$ diameter ciruclar tank containing the array of suspended plastic conduit.

a projected growth rate of $0.08 \mathrm{~cm} /$ day and a planned feed conversion of 1.1.

Total tank weights were recorded to the nearest $0.2 \mathrm{~kg}$ at the conclusion of the experiment. Also at the end of study, ten randomly sampled fish from each tank were weighed to the nearest $0.1 \mathrm{~g}$, and total length was measured to the nearest $1.0 \mathrm{~mm}$.

The following equations were used:

Total weight gain $=$ final tank weight - initial tank weight

Feed conversion ratio $(\mathrm{FCR})=$ total feed fed to tank/total tank weight gained

Condition factor $(\mathrm{K})=10^{5} \times\left[\right.$ weight $\left./(\text { body length })^{3}\right]$

Data were analyzed using the SPSS (24.0) statistical analysis program (Systat Software, Inc., Chicago, Illinois, USA) using one-way Analysis of Variance (ANOVA). Because the tanks were the experimental units, not individual fish, nested ANOVA was conducted on the individual fish data. Because of the small sample sizes $(\mathrm{N}=3)$, significance was pre-determined at $\mathrm{P}<0.10$ [26].

\section{Results}

Feed conversion ratio was significantly improved in the tanks of Atlantic salmon containing environmental enrichment compared to control tanks (Table 1; $\mathrm{F}_{1,4}=$ $4.867, \mathrm{P}=0.092$ ). Final tank weights and weight gain were not significantly different, although the difference in mean gain of $182.0 \mathrm{~kg}$ in the enriched tanks compared to $162.9 \mathrm{~kg}$ in the control tanks approached significance $\left(\mathrm{F}_{1,4}=4.500\right.$, $\mathrm{P}=0.101)$. There were no significant differences observed between the treatments for individual fish body length $\left(\mathrm{F}_{1,4}=0.155, \mathrm{P}=0.714\right)$, weight $\left(\mathrm{F}_{1,4}=\right.$ $0.511, \mathrm{P}=0.514)$, or condition factor $\left(\mathrm{F}_{1,4}=1.596, \mathrm{P}=0.275\right.$; Table 2$)$. Mortality for all tanks was not significantly different and was less than $2 \%$. 
Table 1. Mean \pm SE total tank weights, gain, food fed, and feed conversion ration $\left(F^{2} \mathrm{R}^{\mathrm{a}}\right)$ for Atlantic salmon reared with or without vertically-suspended environmental enrichment structures. Means with different letters within the same row differ significantly $(\mathrm{P}<$ $0.10, \mathrm{~N}=3)$.

\begin{tabular}{ccccc}
\hline Variable & Control & Enriched & $\mathrm{F}_{1,4}$ & $\mathrm{P}$ \\
\hline Rearing days & 168 & 168 & & \\
Initial weight $(\mathrm{kg})$ & $71.5 \pm 0.4$ & $70.9 \pm 0.4$ & 1.373 & 0.306 \\
Final weight $(\mathrm{kg})$ & $232.8 \pm 4.6$ & $251.7 \pm 8.1$ & 4.070 & 0.114 \\
Gain $(\mathrm{kg})$ & $162.9 \pm 4.9$ & $182.0 \pm 7.5$ & 4.500 & 0.101 \\
Food fed (kg) & $184.7 \pm 0.00$ & $184.7 \pm 0.00$ & & \\
FCR & $1.14 \pm 0.03 \mathrm{z}$ & $1.02 \pm 0.04 \mathrm{y}$ & 4.867 & 0.092 \\
\hline
\end{tabular}

${ }^{\mathrm{a}} \mathrm{FCR}=$ total food fed/tank gain.

Table 2. Mean \pm SE individual fish total length, weight, and condition factor $\left(K^{\mathrm{a}}\right)$ for Atlantic salmon reared with or without vertically-suspended environmental enrichment structures $(\mathrm{N}=3)$.

\begin{tabular}{ccccc}
\hline Variable & Control & Enriched & $\mathrm{F}_{1,4}$ & $\mathrm{P}$ \\
\hline Length $(\mathrm{mm})$ & $396 \pm 11$ & $402 \pm 8$ & 0.155 & 0.714 \\
Weight $(\mathrm{g})$ & $744.5 \pm 75.8$ & $802.2 \pm 27.5$ & 0.511 & 0.514 \\
$\mathrm{~K}$ & $1.19 \pm 0.02$ & $1.24 \pm 0.04$ & 1.596 & 0.275 \\
\hline
\end{tabular}

${ }^{\mathrm{a}} \mathrm{K}=10^{5} \times$ individual weight/body length ${ }^{3}$.

\section{Discussion}

The addition of vertically-suspended plastic conduit had positive effects on Atlantic salmon rearing performance when used for 168 days in this experiment. These results differ from White et al. [23], who reported no significant improvement in Atlantic salmon feed conversion or growth after 125 days of rearing with another form of vertically-suspended environmental enrichment in much smaller circular tanks. Study duration may be a crucial determinant for observing significant results. Brockmark et al. [12] observed no effect of environmental enrichment on Atlantic salmon growth after 123 days, but reported growth improvements with enrichment after 311 rearing days. Similarly, White et al. [23] reported that vertically suspended structures did not produce any improvements in brown trout (Salmo trutta) or Chinook salmon (Oncorhynchus tshawytscha) growth at 59 and 78 days, respectively. However, improvements in rearing performance were reported for brown trout growth after 126 days [22] and Chinook salmon at 90 days [21].

This experiment produced similar results to numerous other studies investigating vertically-suspended environmental enrichment during salmonid rearing [18] [19] [20] [21] [22]. Only White et al. [23] was unable to discern any positive effects of such enrichment on the rearing performance of salmonids. Although Näslund and Johnsson [27] suggest that environmental enrichment techniques 
may need to be modified to fit the needs of individual fish species, the consistent results obtained using vertically-suspended structure appear to indicate a more universal response, at least among salmonids.

The alteration of water velocity behind the suspended conduit array may be responsible for the positive affect on Atlantic salmon feed conversion ratio observed in this study. Moine et al. [28] and Muggli et al. [29] reported that vertically-suspended structure arrays produce significant changes in circular tank water velocity profiles, with decreased water velocities behind the arrays. These lower velocity microhabitats likely positively influence fish energy expenditure [18] [30]. In addition, the existence of a variety of in-tank water velocities may allow fish to experience periodic exercise [29] [31]. Exercise from higher velocities is beneficial to fish [32] [33] [34] as long as it is not for extended periods of time [35] [36].

Routine fish husbandry demands were not negatively affected by the use of the conduit arrays in this study. The vertically-suspended environmental enrichment maintained the self-cleaning nature of the circular tanks, as has also been reported by Kientz and Barnes [18], Kientz et al. [19], and White et al. [22]. Although other types of vertically-suspended arrays have been shown to decrease velocities below the level needed for hydraulic self-cleaning [29], the structure used in this study is acceptable for use in production fish hatcheries where circular tanks must be self-cleaning.

Suspended structure did not significantly affect individual fish length, weight, or condition factor. This may be due to small sample sizes [37]. The lack of attention to sexual dimorphism may also have played a role; the ten fish sampled from each tank in this study were chosen at random, without regard to sex. The differences in body size between male and female Atlantic salmon [38] [39] likely produced the relatively high variance in individual fish metrics, which would be particularly pronounced if the sample was dominated by one gender.

\section{Conclusion}

In conclusion, the vertically-suspended environmental enrichment structures used in this study produced improvements in Atlantic salmon rearing performance. It is unknown if such improvements would become more pronounced over a longer rearing period. Given that these structures did not interfere with circular tank hydraulic self-cleaning, their use is recommended during the hatchery rearing of Atlantic salmon. Future studies should focus on even longer study durations, the possible physiological changes induced by the use of vertically-suspended structure, and their potential effects on post-release survival for salmon reared at conservation or recreational fish hatcheries.

\section{Acknowledgements}

We thank Liam Porter, Alissa Muggli, and Sarah White for their assistance with this study. 


\section{Conflicts of Interest}

The authors declare no conflicts of interest regarding the publication of this paper.

\section{References}

[1] Bosakowski, T. and Wagner, E.J. (1995) Assessment of Fin Erosion by Comparison of Relative Fin Length in Hatchery and Wild Trout in Utah. Canadian Journal of Fisheries and Aquatic Science, 51, 636-641. https://doi.org/10.1139/f94-064

[2] Berejikian, B.A., Smith, R.J.F., Tezak, E.P., Schroder, S.L. and Knudsen, C.M. (1999) Chemical Alarm Signals and Complex Hatchery Rearing Habitats Affect Antipredator Behavior and Survival of Chinook Salmon (Oncorhynchus tshawytscha) Juveniles. Canadian Journal of Fisheries and Aquatic Sciences, 56, 830-838. https://doi.org/10.1139/f99-010

[3] Berejikian, B.A., Tezak, E.P., LaRae, A.L. and Riley, S.C. (2001) Competitive Ability and Social Behavior of Juvenile Steelhead Reared in Enriched and Conventional Hatchery Tanks and a Stream Environment. Journal of Fish Biology, 59, 1600-1613. https://doi.org/10.1111/j.1095-8649.2001.tb00224.x

[4] Berejikian, B.A. and Tezak, E.P. (2005) Rearing in Enriched Hatchery Tanks Improves Dorsal Fin Quality of Juvenile Steelhead. North American Journal of Aquaculture, 67, 289-293. https://doi.org/10.1577/A05-002.1

[5] Millidine, K.J., Armstrong, J.D. and Metcalfe, N.B. (2006) Presence of Shelter Reduces Maintenance Metabolism of Juvenile Salmon. Functional Ecology, 20, 839-845.

https://doi.org/10.1111/j.1365-2435.2006.01166.x

[6] Rodewald, P., Hyvärinen, P. and Hirvonen, H. (2011) Wild Origin and Enriched Environment Promote Foraging Rate and Learning to Forage on Natural Prey of Captive Reared Atlantic Salmon Parr. Ecology of Freshwater Fish, 20, 569-579. https://doi.org/10.1111/j.1600-0633.2011.00505.x

[7] Salvanes, A.G.V., Moberg, O., Ebbesson, L.O.E., Nilsen, T.O., Jensen, K.H. and Braithwaite, V.A. (2013) Environmental Enrichment Promotes Neural Plasticity and Cognitive Ability in Fish. Proceedings of the Royal Society B, 280, Article ID: 20131331. https://doi.org/10.1098/rspb.2013.1331

[8] Roberts, L.J., Taylor, J., Gough, P.J., Forman, D.W. and Garcia de Leaniz, C. (2014) Silver Spoons in the Rough: Can Environmental Enrichment Improve Survival of Hatchery Atlantic Salmon Salmo salar in the Wild? Journal of Fish Biology, 85, 1972-1991. https://doi.org/10.1111/jfb.12544

[9] Bergendahl, A.I., Miller, S., Depasquale, C., Giralico, L. and Braithwaite, V.A. (2017) Becoming a Better Swimmer: Structural Complexity Enhances Agility in Captive-Reared Fish. Journal of Fish Biology, 90, 1112-1117. https://doi.org/10.1111/jfb.13232

[10] Berejikian, B.A., Tezak, E.P., Flagg, T.A., LaRae, A.L., Kummerow, E. and Mahnken, C.V.W. (2000) Social Dominance, Growth, and Habitat Use of Age-0 Steelhead (Oncorhynchus mykiss) Grown in Enriched and Conventional Hatchery Rearing Environments. Canadian Journal of Fisheries and Aquatic Sciences, 57, 628-636. https://doi.org/10.1139/f99-288

[11] Brown, C., Davidson, T. and Laland, K. (2003) Environmental Enrichment and Prior Experience of Live Prey Improve Foraging Behaviour in Hatchery-Reared Atlantic Salmon. Journal of Fish Biology, 63, 187-196.

https://doi.org/10.1111/j.1095-8649.2003.00208.x

[12] Brockmark, S., Neregård, L., Bohlin, T., Björnsson, B.T. and Johnsson, J.I. (2007) 
Effects of Rearing Density and Structural Complexity on Pre- and Post-Release Performance of Atlantic Salmon. Transactions of the American Fisheries Society, 136, 1453-1462. https://doi.org/10.1577/T06-245.1

[13] Fast, D.E., Neeley, D., Lind, D.T., Johnston, M.V., Strom, C.R., Bosch, W.J., et al. (2008) Survival Comparison of Spring Chinook Salmon Reared in a Production Hatchery Under Optimum Conventional and Seminatural Conditions. Transactions of the American Fisheries Society, 137, 1507-1518.

https://doi.org/10.1577/T07-143.1

[14] Krebs, J., Crank, K.M., Krebs, E. and Barnes, M.E. (2017) Use of Bottom Structure and Tank Cover During Rainbow Trout Rearing in Circular Tanks. Journal of Fisheries and Livestock Production, 5, 247.

https://doi.org/10.4172/2332-2608.1000247

[15] Tvinnereim, K. and Skybakmoen, S. (1989) Water Exchange and Self-Cleaning in Fish-Rearing Tanks. In: De Pauw, N., et al., Ed., Aquaculture: A Biotechnology in Progress, Vol. 2, European Aquaculture Society, Bredene, 597-1222.

[16] Baynes, S.M. and Howell, B.R. (1993) Observations on the Growth, Survival and Disease Resistance of Juvenile Common Sole, Solea solea (L.), Fed Mytilus edulis L. Aquaculture and Fisheries Management, 24, 95-100. https://doi.org/10.1111/j.1365-2109.1993.tb00831.x

[17] Tuckey, L.M. and Smith, T.I. (2001) Effects of Photoperiod and Substrate on Larval Development and Substrate Preference of Juvenile Southern Flounder, Paralichthys lethostigma. Journal of Applied Aquaculture, 11, 1-20. https://doi.org/10.1300/J028v11n01_02

[18] Kientz, J.L. and Barnes, M.E. (2016) Structural Complexity Improves the Rearing Performance of Rainbow Trout in Circular Tanks. North American Journal of Aquaculture, 78, 203-207. https://doi.org/10.1080/15222055.2016.1159629

[19] Kientz, J.L., Crank, K.M. and Barnes, M.E. (2018) Enrichment of Circular Tanks with Vertically Suspended Strings of Colored Balls Improves Rainbow Trout Rearing Performance. North American Journal of Aquaculture, 80, 162-167. https://doi.org/10.1002/naaq.10017

[20] Crank K.M., Kientz, J.L. and Barnes, M.E. (2019) An Evaluation of Vertically-Suspended Environmental Enrichment during Rainbow Trout Rearing. North American Journal of Aquaculture, 81, 94-100. https://doi.org/10.1002/naaq.10064

[21] Rosburg, A.J., Fletcher, B.L., Barnes, M.E., Treft, C.E. and Bursell, B.R. (2019) Vertically-Suspended Environmental Enrichment Structures Improve the Growth of Juvenile Landlocked Fall Chinook Salmon. International Journal of Innovative Studies in Aquatic Biology and Fisheries, 5, 17-24. https://doi.org/10.20431/2454-7670.0501004

[22] White, S.C., Krebs, E., Huysman, N., Voorhees, J.M. and Barnes, M.E. (2019) Use of Suspended Plastic Conduit Arrays during Brown Trout and Rainbow Trout Rearing in Circular Tanks. North American Journal of Aquaculture, 81, 101-106. https://doi.org/10.1002/naaq.10076

[23] White, S.C., Krebs, E., Huysman, N., Voorhees, J.M. and Barnes, M.E. (2018) Addition of Vertical Enrichment Structures Does Not Improve Growth of Three Salmonid Species during Hatchery Rearing. Journal of Marine Biology and Aquaculture, 4, 48-52. https://doi.org/10.15436/2381-0750.18.1957

[24] Walker, L.M., Parker, T.M. and Barnes, M.E. (2016) Full and Partial Overhead Tank Cover Improves Rainbow Trout Rearing Performance. North American Journal of Aquaculture, 78, 20-24. https://doi.org/10.1080/15222055.2015.1090504 
[25] Buterbaugh, G.L. and Willoughby, H. (1967) A Feeding Guide for Brook, Brown, and Rainbow Trout. Progressive Fish-Culturist, 29, 210-215. https://doi.org/10.1577/1548-8640(1967)29[210:AFGFBB]2.0.CO;2

[26] Cohen, J. (1992) A Power Primer. Psychological Bulletin, 112, 155-159. https://doi.org/10.1037/0033-2909.112.1.155

[27] Näslund, J. and Johnsson, J.I. (2016) Environmental Enrichment for Fish in Captive Environments: Effects of Physical Structures and Substrates. Fish and Fisheries, 17, 1-30. https://doi.org/10.1111/faf.12088

[28] Moine, J., Barnes, M.E., Kientz, J. and Simpson, G. (2016) Flow Patterns in Circular Rearing Tanks Containing Vertical Structure. Journal of Fisheries and Livestock Production, 4, Article ID: 1000204. https://doi.org/10.4172/2332-2608.1000204

[29] Muggli, A.M., Barnes, J.M. and Barnes, M.E. (2019) Vertically-Suspended Environmental Enrichment Alters the Velocity Profiles of Circular Fish Rearing Tanks. World Journal of Engineering and Technology, 7, 208-226. https://doi.org/10.4236/wjet.2019.71014

[30] Fausch, K.D. (1984) Profitable Stream Positions for Salmonids: Relating Specific Growth Rate to Net Energy Gain. Canadian Journal of Zoology, 62, 441-445. https://doi.org/10.1139/z84-067

[31] Kiessling, A., Higgs, D., Dosanjh, B. and Eales, J. (1994) Influence of Sustained Exercise at Two Ration Levels on Growth and Thyroid Function of All-Female Chinook Salmon (Oncorhynchus tshawytscha) in Seawater. Canadian Journal of Fisheries and Aquatic Sciences, 51, 1975-1984. https://doi.org/10.1139/f94-200

[32] Parker, T.M. and Barnes, M.E. (2014) Rearing Velocity Impacts on Landlocked Fall Chinook Salmon (Oncorhynchus tshawytscha) Growth, Condition, and Survival. Open Journal of Animal Sciences, 4, 244-252. https://doi.org/10.4236/ojas.2014.45031

[33] Parker, T.M. and Barnes, M.E. (2015) Effects of Different Water Velocities on the Hatchery Rearing Performance and Recovery from Transportation of Rainbow Trout Fed Two Different Rations. Transactions of the American Fisheries Society, 144, 822-890. https://doi.org/10.1080/00028487.2015.1047533

[34] Lui, G., Wu, Y., Qin, X., Shi, X. and Wang, X. (2018) The Effect of Aerobic Exercise Training on Growth Performance, Innate Immune Response, and Disease Resistance in Juvenile Schizthorax prenanti. Aquaculture, 486, 18-25.

https://doi.org/10.1016/j.aquaculture.2017.12.006

[35] Voorhees, J.M., Barnes, M.E., Chipps, S.R. and Brown, M.L. (2018) Rearing Performance of Juvenile Brown Trout (Salmo trutta) Subjected to Exercise and Dietary Bioprocessed Soybean Meal. Open Journal of Animal Sciences, 8, 303-328. https://doi.org/10.4236/ojas.2018.83023

[36] Voorhees, J.M., Barnes, M.E., Chipps, S.R. and Brown, M.L. (2018) Dietary Bioprocessed Soybean Meal Does Not Affect the Growth of Exercised Rainbow Trout (Oncorhynchus mykiss). Journal of Animal Research and Nutrition, 3, 6. https://doi.org/10.21767/2572-5459.100050

[37] Kuehl, R.O. (2000) Design of Experiments: Statistical Principles of Research Design and Analysis. 2nd Edition, Duxbury Press, Pacific Grove.

[38] Fleming, I.A. (1996) Reproductive Strategies of Atlantic Salmon: Ecology and Evolution. Reviews in Fish Biology and Fisheries, 6, 379-416. https://doi.org/10.1007/BF00164323

[39] Leclercq, E., Taylor, J.F., Hunter, D. and Migaud, H. (2010) Body Size Dimorphism 
of Sea-reared Atlantic Salmon (Salmo salar L.): Implications for the Management of Sexual Maturation and Harvest Quality. Aquaculture, 301, 47-56.

https://doi.org/10.1016/j.aquaculture.2010.01.029 